\title{
Relationship between Academic Achievement and Interest Factors Based on Collaborative Learning Approach among Form Six Economics Students
}

\author{
Noornadiah Md Sari, Khoo Yin Yin*, Zainizam Zakariya, \& Ramlee Ismail \\ Faculty of Management and Economics, Sultan Idris University of Education, Malaysia \\ * E-mail of the corresponding author: khoo@fpe.upsi.edu.my
}

\begin{abstract}
The research is financed by Ministry of Education Malaysia (Sponsoring information)
Abstract

Economic literacy is an essential piece of an individual's daily life regardless of background. An acquaintance of economic literacy empowers individuals to decide rationally in the face of economic issues that impact the lives of communities and nations in a dynamic atmosphere. Malaysia has been in the third phase in executing the Malaysia Education Development Plan (2013-2025). Thus, the Ministry of Education Malaysia took a visionary step by advancing a virtual learning platform called Google Classroom or known as Digital Educational Learning Initiative Malaysia (DELIMa), at the school level. This approach satisfies the learning needs and wants of Generation $\mathrm{Z}$ students. An active learning climate such as a collaborative approach boosts the learning process positively. Nevertheless, the economic achievements and interests of the students identified were not promising. Interest and achievement factors are closely interrelated. Accordingly, this study attempted to identify the perception of students' interest in economic learning and the relationship between interest factors and economic students' achievement based on a collaborative learning approach. This survey study was conducted on 207 Form Six economics students in Malacca, Malaysia. The research instruments involved in collecting data were questionnaires and student achievement tests. The outcomes of the Pearson correlation analysis revealed no significant relationship between interest and achievement factors among economics students. Contextually, this approach could support economics students gain access to and manage learning content more easily. The researcher proposes that this learning by the Google Classroom-assisted digital platform approach be continued in the future to facilitate students to access learning content. The conclusions of this study confirmed that futuristic pedagogical methods such as cybersecurity, gamification and heutagogy would complement the landscape of the learning environment in Malaysia in the future. Thus, added studies on other factors that support the efficacy of the implementation of digital collaborative learning approaches should be developed.
\end{abstract}

Keywords: Academic Achievement; Interest; Google Classroom; Online Learning; Economics Education.

DOI: $10.7176 / \mathrm{JEP} / 13-1-01$

Publication date: January $31^{\text {st }} 2022$

\section{Introduction}

The use of technology applications in education is typical nowadays. This is in line with the seventh shift of the Education Development Plan 2013-2025 concentrates on enhancing the quality of learning in Malaysia by leveraging ICT (MOE, 2013). This approach is in line with the lifestyle of today's generation Z students, who are significantly acquainted with the use of technology. Al-Emran (2019) mentioned that students and academics with technological facilities are more likely to use a mobile learning approach than students who do not have equipment. Hence, the Ministry of Education Malaysia took a proactive measure by introducing a virtual learning platform called Google Classroom or known as Digital Educational Learning Initiative Malaysia (DELIMa), at the school level. Educators in Malaysia value the use of the Google Classroom application. The number of Google Classroom users in Malaysia until November 2021 recorded the second-highest out of 64 countries (Google Trend, 2021).

The Google Classroom app delivers services such as managing class schedules, providing online and offline communication, sharing files, creating and organising assignments, and providing feedback efficiently to facilitate users to interact and cooperate (Jamiludin et al., 2021; Widiyatmoko, 2021). Based on the social learning theory of constructivism (Vygotsky, 1987), the formation of fresh knowledge results during social interaction. Students obtain senses from eclectic viewpoints during collaborative learning, receive feedback from group members, and analyse ideas until an absolute understanding agreement is attained (Stacey, 1999). A student-centred active learning approach that uplifts student interaction is desirable, such as collaborative learning (Islam et al., 2021; Mugizi et al., 2021; Scager et al., 2016). This approach is suitable to be implemented for economics students in form six because compared with the control group, students have obtained greater benefits in terms of self-efficacy, self-regulation and ability to think at a high level of learning lessons (Micari \& Pazos, 2020; Noornadiah \& Khoo, 2021a). Further, the learning content can also be accessed wherever using the Google Classroom application through mobile device devices such as laptops and smartphones (Dash, 2019). In addition, the convenience of communication tools and internet lines that can be accessed facilitates communication between students. The 
experimental study of Haggag (2019) and Tan et al. (2015) reported that advancement in achievement in the treatment group exposed to Google Classroom was better than the control group. Nonetheless, the contrasting discovery by Huang et al. (2021) found no difference in the achievement of the treatment and control groups of students.

In general, collaborative learning encourages individual student-centred learning. Students hold a second alternative by asking other team members instead of relying on the teacher's problem-solving. The relevance of implementing an active learning approach relies upon improving reasoning skills among economics students (Ayers, 2018). Many researchers have applied collaborative learning approaches to test its impact on economics student achievement. This is because the positive impact of social factors occurs (interaction with friends and teachers, social presence and use of social media) during the learning process impacts on active collaborative learning and student engagement, further leading to ameliorated learning undertaking (Al-Rahmi et al., 2018; Molinillo et al., 2018; Qureshi et al., 2021). Birgili et al. (2021) too agreed that the learning approach helps them better comprehend the concept and construct a closer relationship between instructors and students.

Previous researchers have also proposed implementing active teaching and learning approaches among economics students to increase student interest and achievement (Marburger, 2005; Ramlee et al, 2020). Research evidence of Yamarik (2007) and Chen and Lin (2020) on higher education economics students established an increase in the achievement of economics students on students exposed to the active learning approach. In line with recent developments, collaborative learning is not limited to the classroom and can even be applied using digital learning mediums. An experimental analysis by Calimeris (2018) proved that the flipped classroom economics learning approach showed effective improvement in economics exam achievement compared to the control group students. In addition to cognitive development, past findings also documented the occurrence of socio-cognitive development during social interaction among students. Collaborative learning approaches can improve the efficiency of teamwork, communication, creativity, organisation and information management (Parrado-Martínez \& Sánchez-Andújar, 2020). Besides, collaborative learning can enhance other non-cognitive facets such as self-efficacy (Noornadiah \& Khoo, 2021a), attitudes (Noornadiah et al., 2021) and students' interest in economic learning (Noornadiah \& Khoo, 2021b; Ramlee et al., 2020). Nevertheless, several reports confirmed contrasting data, such as research of Shawver (2020) and Cannonier and Smith (2018). It offered no increase in exam achievement for students exposed to collaborative learning. Student results were lower than the group studying alone. According to Cannonier and Smith (2018), sometimes, the collaborative process could hinder the performance of some students. Furthermore, Emerson et al. (2016) unveiled that some students maintained less positive perceptions regarding cooperative learning activities.

\subsection{Problem Statement}

Weak economics students were identified to have weaknesses in high-level skills, namely reasoning skills (Ayers, 2018). Malaysian Higher School Certificate questions also include high-level skills. Statistical evidence of the achievement of Malaysian Higher School Certificate students in economics subjects was lower than the achievement of business studies students. Based on the comparison of the mean percentage of passing national business and economics studies from 2015 to 2019, as shown in Table 1, it appears that the full pass performance of economics subjects at the national level was still at a lower level each year from 2015 to 2019 (MPM, 2020). The mean score of economic full passing was only $76.86 \%$ compared to the achievement of business studies subjects $82.58 \%$. The percentage of students who fail in economics $(4.07 \%)$ is also higher than that in business studies $(3.73 \%)$.

According to Schnell and Loerwald (2019) and Wunder (2013), the weakness of academic achievement originates from the factor of students' interest in economic learning. A review of the literature reported a positive relationship between the variables of interest and the achievement of economics students (Kara et al., 2009; Schnell \& Loerwald, 2018). Students with low interest tend to get lower results than students with high interest (Bach \& Saunders, 1965; Juttler, 2020). Low interest causes students not to focus while teachers teach especially economic topics involving high intrinsic loads such as graph and data interpretation skills and economic curves (Davis, 2019). Moreover, the exposure of this subject was less to students compared to other subjects (Lodewijks et al., 2016). This situation leads to an awareness of the essence of low economic literacy values, the perception of some students consider economics to be a petty and unpleasant subject in the class (Jack \& Lin, 2018). Low-interest factors, in turn, would affect the construction of negative self-efficacy (Grigg et al., 2018). 
Table 1. Comparison of Mean Percentage of Passing Achievements Malaysian Higher School Certificate in Business and Economics from 2015 to 2019

\begin{tabular}{ccccccc}
\hline \multirow{2}{*}{ Year } & \multicolumn{2}{c}{ Full Pass (\%) } & \multicolumn{2}{c}{ Partial Pass (\%) } & \multicolumn{2}{c}{ Fail (\%) } \\
\cline { 2 - 7 } & Business & Economics & Business & Economics & Business & Economics \\
\hline 2015 & 84.48 & 74.59 & 12.67 & 21.2 & 2.85 & 4.21 \\
2016 & 85.52 & 76.95 & 12.14 & 18.37 & 2.35 & 4.69 \\
2017 & 80.75 & 76.23 & 15.7 & 19.95 & 3.53 & 3.81 \\
2018 & 81.59 & 78.06 & 14.7 & 18.64 & 3.71 & 3.3 \\
2019 & 80.54 & 78.46 & 13.27 & 17.2 & 6.19 & 4.33 \\
\hline Mean & 82.58 & 76.86 & 13.70 & 19.07 & 3.73 & 4.07 \\
\hline
\end{tabular}

\subsection{Research Objectives}

A review of the literature found that the economic achievement and interest of the students identified were not encouraging. Accordingly, this study was conducted to identify the relationship of interest factors and academic achievement based on Google Classroom-assisted collaborative learning approach among economics students. Previous research has often concentrated on the effects of collaborative learning on interest and academic achievement in the classroom. This implies that research gaps need to be explored to identify the relationship between interest and achievement in this new environment.

\subsection{Research Methodology}

This survey study was conducted on Form Six economics students in Malacca. The participating respondents consisted of 207 students who were selected by random cluster sampling. The researcher employed a five-point Likert scale questionnaire instrument of 1 (strongly disagree) to 5 (strongly agree) to obtain data on student interest (13 items). While the economic achievement test instrument consisted of 30 economic (semester 1) multiple answers questions to measure the achievement of economics students. The reliability of the achievement test instrument and the study questionnaire and the achievement test were based on Cronbach's alpha values of 0.92 and 0.80 . When the result of Cronbach's Alpha is higher than 0.70 , it showed a high-reliability standard (Sekeran $\&$ Bougie, 2010). Thus, the reliability of this research instrument was high and suitable for use in actual studies. The researcher first applied for permission from the Education Policy Planning and Research Department of (EPRD), Malacca State Education Department, school principals and student participation agreement. Data were analysed using descriptive analysis and pearson correlation inferential analysis to measure the relationship of academic achievement and student interest based on the collaborative learning approach conducted on students.

\subsection{Result}

5.1 Demographic Distribution of Respondents

The distribution of demographic profiles of study participants is shown in Figure 1, consisting of gender, race, location of residence, estimated family income, number of devices owned, experience using device devices and frequency of internet use. The distribution of respondents showed that the number of female students $(68.9 \%)$ was more than male students $(31.1 \%)$. While for the distribution by race, Chinese students recorded $64.1 \%$, followed by Malay students $(31.6 \%)$, Indians $(4.4 \%)$ and others. The distribution of students by residence location indicated that most students were from urban (69.4\%) and rural $(30.6 \%)$. Besides, the distribution of students from B40 group families with less RM 4849 income built (46.6\%) and M40 families (family with an income between RM 4849 to RM 10959 ) composed (45.6\%) and followed by T20 group families (family with an income more than RM 10 959) formed (7.8\%). Additionally, in terms of the number of devices owned, the majority of them owned one to two gadgets $(72.6 \%)$, followed by three to four gadgets $(13.1 \%)$ and $(10.7 \%)$ of them owned more than four gadgets. No students reported with no gadgets. The distribution of user experience discovered that $48.1 \%(99$ people) had experience using the gadgets of four to seven years, followed by an experience period of more than seven years $(41.7 \%)$ and less than four years $(10.2 \%)$. Of the total study participants, $48.6 \%$ would allocate one to six hours on internet usage per day, $40.3 \%$ seven to 12 hours per day, and more than 12 hours $(11.2 \%)$. 


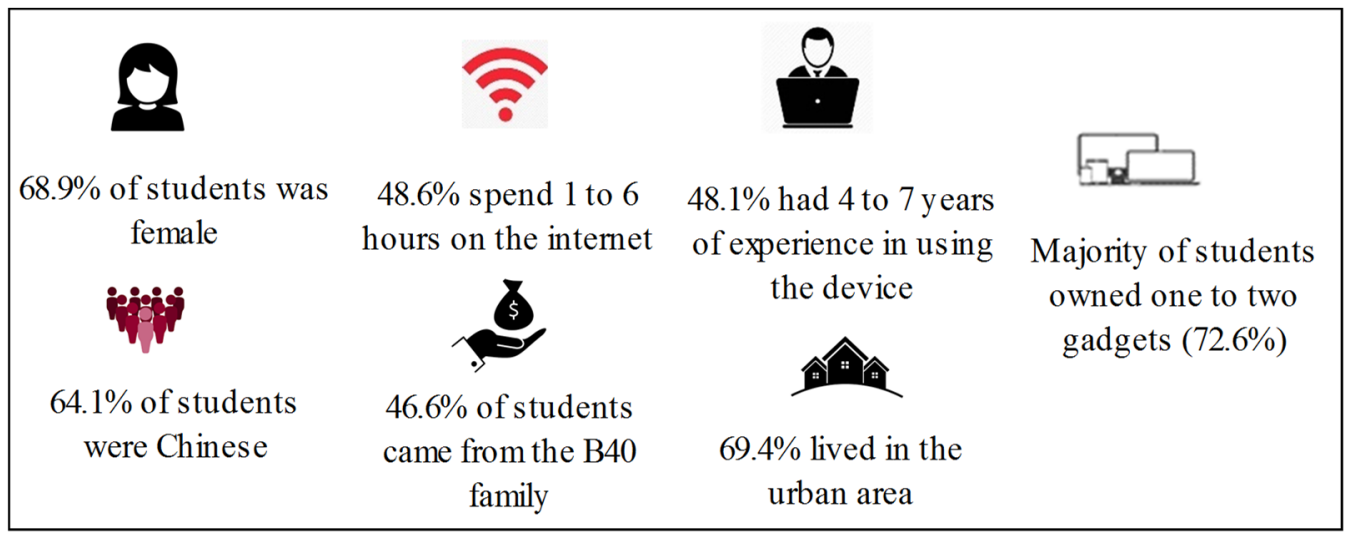

Figure 1. Distribution of Study Respondents

\subsection{Perceptions of Student Interest}

The study's findings summarise the perception of students' interest in economic learning as in Table 2. Students had a high perception of interest in economic learning because each item recorded a high mean value (3.01 to 4.00) (Nunally, 1978). The role of economics teachers was dominant in influencing students' interest because students' dependence on teachers was high such as item B9 "I ask the teacher about a question that I do not understand." $(\mathrm{M}=4.04, \mathrm{SD}=0.87)$ and item B11 "I rely entirely on the teacher's teaching in the classroom" $(\mathrm{M}=4.11, \mathrm{SD}=$ 0.79). However, students were less likely to choose a career in economics in the future when item B13, "I will choose an economics-related career in the future" $(\mathrm{M}=3.36, \mathrm{SD}=1.09)$, showed a lower mean score than other items.

Table 2. Perceptions of Student Interest in Economic Learning

\begin{tabular}{|l|l|c|c|}
\hline \multicolumn{2}{|c|}{ Item } & Mean & Standard deviation \\
\hline B1 & I enjoy learning economics. & 3.80 & 0.78 \\
\hline B2 & Economics is one of my favourite subjects. & 3.49 & 0.92 \\
\hline B3 & I realise economics is useful in my daily life. & 3.96 & 0.90 \\
\hline B4 & I make better decisions based on the economic concepts I learned. & 3.73 & 0.85 \\
\hline B5 & I give my opinion even if the opinion is contrary to that of others. & 3.44 & 0.95 \\
\hline B6 & I try to find additional information on an economic issue. & 3.44 & 0.92 \\
\hline B7 & $\begin{array}{l}\text { While in class, I am willing to share general knowledge with other } \\
\text { friends. }\end{array}$ & 3.73 & 0.93 \\
\hline B8 & I engage in group work assignment discussions. & 3.87 & 0.87 \\
\hline B9 & I ask the teacher about a question that I do not understand. & 4.04 & 0.87 \\
\hline B10 & $\begin{array}{l}\text { I get additional economic reading material and the notes given by the } \\
\text { teacher. }\end{array}$ & 3.78 & 1.06 \\
\hline B11 & I rely entirely on the teacher's teaching in the classroom. & 4.11 & 0.79 \\
\hline B12 & I learn interesting new knowledge about the country's economy. & 3.99 & 0.96 \\
\hline B13 & I will choose an economics-related career in the future. & 3.36 & 1.09 \\
\hline
\end{tabular}

\subsection{The Relationship between Student Academic Achievement and Interest in Economics Learning}

Next, the pearson correlation test was implemented to determine the relationship between students' achievement and interest in economic learning. The analytical information reported in Table 2 confirmed that the student interest variable had no significant relationship with student achievement in economics learning. The Pearson value of $r$ was $(207, p=.767)=0.021, p>.05$. The value of the coefficient $(r=0.021)$ was not significant at the 0.05 significance level. These findings established no relationship between interest and achievement in economics learning of form six students.

Table 2. Pearson Correlation Analysis Between Academic Achievement Variables and Students' Interest in Economics Learning

\begin{tabular}{ccccc}
\hline Variable & $\mathrm{N}$ & Student achievement (r) & Student interest (r) & Sig. \\
\hline Student achievement & 207 & 1 & 0.021 & .767 \\
\hline
\end{tabular}

\subsection{Study Discussion}

This study aimed to identify the relationship between the variables of interest and student achievement based on the collaborative learning approach among Form Six economics students. Pearson correlation analysis was conducted to identify whether there was a relationship between the two variables or not. The results of the analysis 
carried out by the researcher unearthed no significant relationship $(\mathrm{p}>.05)$ on the variables of student interest and achievement.

The results of this research are also supported by prior research reports such as Potvin et al. (2020), Nabizadeh et al. (2019), Wong and Wong (2019), Premo et al. (2018), Koller et al. (2001) and De Fruyt and Mervielde (1996). The 2012 international assessment of PISA also registered that the interest variable imposed no relationship with student achievement over students in Malaysia (Thien \& Ong, 2015). Although PISA assessments are more focused on mathematics, Jeschke et al. (2019) and Garofalo (1990) noted that mathematical competence is a necessity for students to master the content of economic learning. Additionally, several past research documented a positive relationship of interest factors on economics student achievement (Kara et al., 2009; Schnell \& Loerwald, 2018). Researchers provided several rationales to explain the results obtained, such as the need to master basic skills at the beginning of learning, the goals of the current learning environment, the need for teacher support and external factors.

Michaelides et al. (2019) maintained that individual abilities are the most influential factors in the relationship between student motivation and achievement. At the beginning of the semester, several Form Six economics students intended to test their ability in the academic field, whether they could continue their studies or otherwise (Ramlee \& Khoo, 2020). In addition to communication skills, technical skills need to be mastered in implementing online learning in the early stages of learning (Almekhlafy, 2021; Eynon \& Malmberg, 2020). The problems students encounter throughout online collaborative learning could be the causality for the lack of learning effectiveness (Al-Rawahi \& Al-Mekhlafi, 2015; Sadiq Rabab'h \& Veloo, 2015). Thus, Lei and Medwell (2021), Sumuer (2018) and Lee et al. (2014) suggested that students receive exposure and technical training at the commencement of the learning period. In this research, the respondents consisted of first-semester economics students who were recently exposed to Google Classroom. Hence, in the early stages of learning, students need to master the skills over academic achievement.

The next factor is due to the cultural change of the learning environment, emphasizing the skills process and the highlight on examination scores. Learning in Form Six aims to develop individual talents and creativity (MOE, 2019). Therefore, the development of self-directed students, 21 st-century skills and soft skills are underscored (Nasir \& Mohd Yunus, 2017). This is in line with the learning goals of technical and vocational education to produce students who can use wisdom in daily life and professional life later (Nur Fatin, 2015). Priority to mastery skills throughout the learning process is also an added value and preparation for higher education later. Students in Form Six consist of adult category students. Therefore, the andragogy learning approach is pertinent to implement. Learning is momentous when it is assimilated into students' daily life occasions (Yang, 2014, 2017). This discussion aligns with the short-term findings, where student interest did not correlate with economic student achievement alone.

Further evidence in line with the research of Wong and Wong (2019) found that low-achieving students reported better interest than high-achieving students. This means that students are aware of the essence of economics but do not demonstrate competence in economics. They need supportive help in answering challenging economic questions. Extrinsic stimuli such as getting good exam scores have been shown to have a weak effect on the relationship of interest and achievement (Koller et al., 2001) but not directly (Yu \& Sing, 2016). Furthermore, in the context of the current learning environment during the COVID-19, it urges the implementation of teaching and learning carried out from home. Exhaustion of facing computer screens (Rizvi \& Nabi, 2021) and anxiety of dealing with the current learning surroundings do not promote achievement (Roman \& Plopeanu, 2021; Sung et al., 2016). Hence, students need teacher support based on students' abilities in stages.

This research could not prove a relationship between the variables of interest and achievement. It might be due to the assessment on the interest factors and the level of students' mastery not being done specifically (Renninger \& Hidi, 2002). The researcher believes interest factors still play a role as predictors of student achievement in the long run (Adamma et al., 2018; Renninger \& Hidi, 2002). Individual interests are developed through several phases of interest development, such as trigger and interest retention stages (Harackiewicz et al., 2016; Hidi \& Renninger, 2006; Renninger et al., 2018). The data of Schnell and Loerwald (2019) noted that the relationship of interest and economic achievement established a positive relationship when the influencing external factors were controlled. In addition to student interest factors, student achievement is also influenced by more dominant factors such as teacher, school, and family (Suhaini et al., 2020). In this study, these dominant external factors were not controlled, therefore indirectly contributing to the possibility of the findings not demonstrating a relationship between interest factors and economic achievement.

\subsection{Conclusion}

Ergo, this research documented no relationship between the variables of interest and student achievement among economics students. Based on the arguments afforded, the possibility of individual ability factors, changes in the current learning culture, the need for teacher support and the influence of external factors clarify the results obtained. Additionally, it confirmed that the affective aspects of students' interests need to be considered and 
strengthened before assessing cognitive abilities to overcome economic learning drawbacks. The increasingly demanding environment inspires teachers to innovate in teaching. This study contributes to using the constructivism social learning approach through digital platforms. Social interaction now goes beyond the classroom background in line with current technological developments. Contextually, this approach could help economics students gain access to and manage learning content more easily. This study was only limited to economics students in semester one in one state. Hence, generalising the study's findings is impossible for all Form Six economics students. The researcher urges that the next researcher involve more respondents in matriculation and pre-university, which offer economics courses. In addition, the researcher recommends that the next researcher conduct interviews to obtain more exhaustive conclusions. This study holds implications for students, teachers and policymakers. This approach meets Generation Z students' learning needs and wants, prioritising interactive e-learning, real-time learning, and collaborative learning (Poláková \& Klímová, 2021). Teachers and students need to be ready for the transformation of education with mastery of the digital medium. Mastery of technological literacy leads to diverse teaching and learning approaches for economics students. Policymakers need to devise and implement workshops or programs in improving technology literacy on prospective teachers and teachers over time. The conclusions of this study validated that futuristic pedagogical methods such as cybersecurity, gamification and heutagogy would complement the landscape of the learning environment in Malaysia in the future. The researcher submits that this Google Classroom-assisted digital platform approach be continued to boost students access to learning content. Accordingly, further studies on other factors that support the effectiveness of the implementation of digital collaborative learning approaches should be established. In addition, it is recommended that future researchers study other factors that may contribute to economic achievement, such as self-efficacy and student attitudes.

\section{References}

Adamma, O. N., Ekwutosim, O. P., \& Unamba, E. C. (2018). Influence of extrinsic and intrinsic motivation on pupils academic performance in mathematics. Supremum Journal of Mathematics Education (SJME), 2(2), 52-59. https://doi.org/10.5281/zenodo.1405857

Al-Emran, M., Alkhoudary, Y. A., Mezhuyev, V., \& Al-Emran, M. (2019). Students and educators attitudes towards the use of m-learning: Gender and smartphone ownership differences. International Journal of Interactive Mobile Technologies (iJIM), 13(01), 127-135. https://doi.org/10.3991/ijim.v13i01.9374

Almekhlafy, S. S. A. (2021). Online learning of english language courses via blackboard at Saudi universities in the era of COVID-19: Perception and use. PSU Research Review, 5(1), 16-32. https://doi.org/10.1108/PRR08-2020-0026

Al-Rahmi, W. M., Alias, N., Othman, M. S., Marin, V. I., \& Tur, G. (2018). A model of factors affecting learning performance through the use of social media in Malaysian higher education. Computers \& Education, 121, 59-72. https://doi.org/10.1016/j.compedu.2018.02.010

Al-Rawahi, L.S., \& Al-Mekhlafi, A.M. (2015). The effect of online collaborative project-based learning on english as a foreign language learners' language performance and attitudes. Learning and Teaching in Higher Education: Gulf Perspectives, 12(2). https://doi-org.ezpustaka2.upsi.edu.my/10.18538/lthe.v12.n2.186

Ayers, C. A. (2018). A first step toward a practice-based theory of pedagogical content knowledge in secondary economics. The Journal of Social Studies Research, 42(1), 61-79. https://doi.org/10.1016/j.jssr.2017.01.003

Bach, G., \& Saunders, P. (1965). Economic education: Aspirations and achievements. The American Economic Review, 55(3), 329-356.

Birgili, B., Seggie, F. N., \& Oğuz, E. (2021). The trends and outcomes of flipped learning research between 2012 and 2018: A descriptive content analysis. Journal of Computers in Education, 8(3), 365-394. https://doi.org/10.1007/s40692-021-00183-y

Calimeris, L. (2018). Effects of flipping the principles of microeconomics class: Does scheduling matter? International Review of Economics Education. https://doi.org/10.1016/j.iree.2018.01.002

Cannonier, C., \& Smith, K. (2018). Do crib sheets improve student performance on tests? Evidence from principles of economics. International Review of Economics Education. https://doi.org/10.1016/j.iree.2018.08.003

Chen, J., \& Lin, T. F. (2020). Do cooperative-based learning groups help students learn microeconomics? SAGE Open, 10(3), 215824402093869. https://doi.org/10.1177/2158244020938699

Dash. S. (2019). Google classroom as a learning management system to teach biochemistry in a medical school. Biochemistry and Molecular Biology Education. https://doi.org/10.1002/bmb.21246

Davis, M. E. (2019). Poetry and economics: Creativity, engagement and learning in the economics classroom. International Review of Economics Education. https://doi.org/10.1016/j.iree.2019.100155

De Fruyt, F., \& Mervielde, I. (1996). Personality and interests as predictors of educational streaming and achievement. European Journal of Personality, 10, 405-425.

Emerson, T. L. N., English, L., \& McGoldrick, K. (2016). Cooperative learning and personality types. International Review of Economics Education, 21, 21-29. https://doi.org/10.1016/j.iree.2015.12.003 
Eynon, R., \& Malmberg, L. (2020). Lifelong learning and the Internet: Who benefits most from learning online? British Journal of Educational Technology. https://doi.org/10.1111/bjet.13041

Garofalo, J. (1990). What mathematical competencies are needed for success in college. Research and Teaching in Developmental Education, 7(1), 75-84. https://www.jstor.org/stable/42801794

Google Trends, (2021). Google Classroom. https://trends.google.com/trends/explore?q=google\%20classroom

Grigg, S., Perera, H. N., McIlveen, P., \& Svetleff, Z. (2018). Relations among math self efficacy, interest, intentions, and achievement: A social cognitive perspective. Contemporary Educational Psychology, 53, 7386. https://doi.org/10.1016/j.cedpsych.2018.01.007

Haggag, M.H. (2019). Using google classroom in enhancing communicative grammar use and attitudes of nonenglish specialized post graduates. European Scientific Journal, 15(1). http://dx.doi.org/10.19044/esj.2019.v15n1p261

Harackiewicz, J. M., Smith, J. L., \& Priniski, S. J. (2016). Interest matters. Policy Insights from the Behavioral and Brain Sciences, 3(2), 220-227. https://doi.org/10.1177/2372732216655542

Hidi, S., \& Renninger, K. A. (2006). The four-phase model of interest development. Educational Psychologist, 41(2), 111-127. https://doi.org/10.1207/s15326985ep4102_4

Huang, T. H., Liu, F., Chen, L. C., \& Tsai, C. C. (2021) The acceptance and impact of Google Classroom integrating into a clinical pathology course for nursing students: A technology acceptance model approach. PLoS ONE, 16(3). https://doi.org/10.1371/journal.pone.024781

Islam, M. K., Sarker, M. F. H., \& Islam, M. S. (2021). Promoting student-centred blended learning in higher education: A model. E-Learning and Digital Media. https://doi.org/10.1177/20427530211027721

Jack, B. M., \& Lin, H. (2018). Warning! Increases in interest without enjoyment may not be trend predictive of genuine interest in learning science. International Journal of Educational Development, 62, 136-147. https://doi.org/10.1016/j.ijedudev.2018.03.005

Jamiludin, Darnawati, Uke, W.A.S., \& Salim. (2021). The use of google classroom application in a blended learning environment. Journal of Physics: Conference Series. https://doi.org/10.1088/1742$6596 / 1752 / 1 / 012066$

Jeschke, C., Kuhn, C., Lindmeier, A., Zlatkin-Troitschanskaia, O., Saas, H., \& Heinze, A. (2019). What is the relationship between knowledge in mathematics and knowledge in economics? Investigating the professional knowledge of (pre-service) teachers trained in two subjects. Zeitschrift für Pädagogik, 65(4), 511-524.

Juttler, M. (2020) Predicting economics student retention in higher education: The effects of students' economic competencies at the end of upper secondary school on their intention to leave their studies in economics. PLoS ONE, 15(2). https://doi.org/10.1371/journal.pone.0228505

Kara, O., Bagheri, F., \& Tolin, T. (2009). Factors affecting students' grades in principles of economics. American Journal of Business Education, 2(7).

Koller, O., Baumert, J., \& Schnabel, K. (2001). Does interest matter? The relationship between academic interest and achievement in mathematics. Journal for Research in Mathematics Education, 32(5), 448. https://doi.org/10.2307/749801

Lee, K., Tsai, P.-S., Chai, C. S., \& Koh, J. H. L. (2014). Students' perceptions of self-directed learning and collaborative learning with and without technology. Journal of Computer Assisted Learning, 30(5), $425-437$. https://doi.org/10.1111/jcal.12055

Lei, M., \& Medwell, J. (2021). Impact of the COVID 19 pandemic on student teachers: How the shift to online collaborative learning affects student teachers' learning and future teaching in a Chinese context. Asia Pacific Education Review, 22(2), 169-179. https://doi.org/10.1007/s12564-021-09686-w

Lodewijks, J., Stokes, A., \& Wright, S. (2016). Economics: An elite subject soon only available in elite universities? International Review of Economics Education, 23, 1-9. https://doi.org/10.1016/j.iree.2016.06.001

Majlis Peperiksaan Malaysia (MPM). (2020). Keputusan peperiksaan Ekonomi dan Pengajian Perniagaan STPM (2015-2019) Peringkat Kebangsaan. Majlis Peperiksaan Malaysia.

Marburger, D. R. (2005). Comparing student performance using cooperative learning. International Review of Economics Education, 4(1), 46-57. https://doi.org/10.1016/S1477-3880(15)30138-9

Micari, M., \& Pazos, P. (2020). Beyond grades: improving college students' social-cognitive outcomes in STEM through a collaborative learning environment. Learning Environments Research. https://doi.org/10.1007/s10984-020-09325-y

Michaelides, M.P., Brown, G.T.L., Eklöf, H., \& Papanastasiou, E.C. (2019). The relationship of motivation with achievement in mathematics. In: Motivational profiles in TIMSS mathematics. IEA Research for Education (A Series of In-depth Analyses Based on Data of the International Association for the Evaluation of Educational Achievement (IEA)), vol. 7. Springer, Cham. https://doi.org/10.1007/978-3-030-26183-2 2

Ministry of Education (MOE). (2013). Malaysia education blueprint 2013-2025. https://www.moe.gov.my/muatturun/penerbitan-dan-jurnal/1818-pelan-pembangunan-pendidikan-2013-2025/file

Ministry of Education (MOE). (2019). Goal. https://www.moe.gov.my/pendidikan/lepas-menengah/tingkatan- 
6/matlamat

Molinillo, S., Aguilar-Illescas, R., Anaya-Sánchez, R., \& Vallespín-Arán, M. (2018). Exploring the impacts of interactions, social presence and emotional engagement on active collaborative learning in a social web-based environment. Computers \& Education, 123, 41-52. https://doi.org/10.1016/j.compedu.2018.04.012

Mugizi, W., Katuramu, A. O., Dafiewhare, A. O., \& Kanyesigye, J. (2021). Student-centred pedagogical approach and student engagement at a private university in Western Uganda. Education Journal. 10(5), 193-203. https://doi.org/10.11648/j.edu.20211005.14

Nabizadeh, S., Hajian, S., Sheikhan, Z., \& Rafiei, F. (2019). Prediction of academic achievement based on learning strategies and outcome expectations among medical students. BMC Medical Education, 19(1). https://doi.org/10.1186/s12909-019-1527-9

Nasir, M., \& Mohd Yunus, H. (2017). Peranan guru tingkatan enam dalam membentuk pelajar terarah kendiri dan meningkatkan kemahiran abad ke-21. Jurnal Kurikulum \& Pengajaran Asia Pasifik, 5(1), 1-6.

Noornadiah, M. S., \& Khoo, Y. Y. (2021a). The effect of google classroom-assisted learning on self- efficacy among form six economics students. International Journal of Academic Research in Business and Social Sciences, 11(11), 1922-1938. https://doi.org/10.6007/IJARBSS/v11-i11/11527

Noornadiah, M. S., \& Khoo, Y. Y. (2021b). The effect of google classroom assisted learning on interest among form six economics students. International Journal of Academic Research in Progressive Education and Development, 10(4), 107-120. http://dx.doi.org/10.6007/IJARPED/v10-i4/11503

Noornadiah, M. S., Khoo, Y. Y., \& Zainizam, Z. (2021). The impact of google classroom-assisted collaborative learning approach on economics students' attitudes. International Journal of Advanced Research in Education and Society, 3(4), 21-37. https://myjms.mohe.gov.my/index.php/ijares/article/view/16353

Nunnally, J. C. (1978). Psychometric theory (2nd ed). McGraw-Hill.

Nur Fatin, M. S. (2015). Technical and vocational education transformation in Malaysia: Shaping the future leaders. Journal of Education and Practice, 6(22).

Parrado-Martínez, P., \& Sánchez-Andújar, S. (2020). Development of competences in postgraduate studies of finance: A project-based learning (PBL) case study. International Review of Economics Education, 35. https://doi.org/10.1016/j.iree.2020.100192

Poláková, \& Klímová. (2019). Mobile technology and generation Z in the english language classroom - A preliminary study. Education Sciences, 9(3), 203. https://doi.org/10.3390/educsci9030203

Potvin, P., Hasni, A., Ayotte-Beaudet, J. P., \& Sy, O. (2020). Does individual interest still predict achievement in science and technology when controlling for self-concept? A longitudinal study conducted in Canadian schools. EURASIA Journal of Mathematics, Science and Technology Education, 16(12).

Premo, J., Cavagnetto, A., Davis, W. B., \& Brickman, P. (2018). Promoting collaborative classrooms: The impacts of interdependent cooperative learning on undergraduate interactions and achievement. CBE-Life Sciences Education, 17(2). https://doi.org/10.1187/cbe.17-08-0176

Qureshi, M. A., Khaskheli, A., Qureshi, J. A., Raza, S. A., \& Yousufi, S. Q. (2021). Factors affecting students' learning performance through collaborative learning and engagement. Interactive Learning Environments, 121. https://doi.org/10.1080/10494820.2021.1884886

Ramlee, I., \& Khoo, Y.Y. (2020).The impact of policy changes at the pre-university education on teaching, learning, and student performance. Universal Journal of Educational Research, 8(3), 1037-1045.

Ramlee, I., Marinah, A., Seow, Y. P., \& Muhammad Ridhuan, B. A. (2020). Active learning in economic subject: A case study at secondary school. International Journal of Learning, Teaching and Educational Research, 19 (10), 19-31. https://doi.org/10.26803/ijlter.19.10.2

Renninger, K. A., Bachrach, J. E., \& Hidi, S. E. (2018). Triggering and maintaining interest in early phases of interest development. Learning, Culture and Social Interaction. https://doi.org/10.1016/j.lcsi.2018.11.007

Renninger, K. A, \& Hidi, S. (2002). Student interest and achievement. Development of Achievement Motivation, 173-195. https://doi.org/10.1016/B978-012750053-9/50009-7

Rizvi, Y.S., \& Nabi, A. (2021). Transformation of learning from real to virtual: An exploratory descriptive analysis of issues and challenges. Journal of Research in Innovative Teaching \& Learning, 14(1), 5-17. https://doi.org/10.1108/JRIT-10-2020-0052

Roman, M., \& Plopeanu, A. (2021). The effectiveness of the emergency eLearning during COVID-19 pandemic. The case of higher education in economics in Romania. International Review of Economics Education, 37(54).

Sadiq Rabab'h, B., \& Veloo, A. (2015). Prediction of mathematics learning strategies on mathematics achievement among 8th grade students in Jordan. Asian Social Science, 11(2). https://doi.org/10.5539/ass.v11n2p276

Scager, K., Boonstra, J., Peeters, T., Vulperhorst, J., \& Wiegant, F. (2016). Collaborative learning in higher education: Evoking positive interdependence. CBE-Life Sciences Education, 15(4). https://doi.org/10.1187/cbe.16-07-0219

Schnell, C., \& Loerwald, D. (2018). Interest as an influencing factor on student achievement in economics evidence from a study in secondary schools in Germany. International Review of Economics Education. 
Schnell, C., \& Loerwald, D. (2018). Interest as an influencing factor on student achievement in Economics. International Review of Economics Education. doi:10.1016/j.iree.2018.03.005 (https://doi.org/10.1016/j.iree.2018.03.005)

Sekeran, U., \& Bougie, R.. (2010). Research methods for business: A skill building approach (5th ed). John Willey $\&$ Sons Ltd.

Shawver, T. J. (2020). An experimental study of cooperative learning in advanced financial accounting courses. Accounting Education, 29(3), 247-262. https://doi.org/10.1080/09639284.2020.1736589

Stacey, E. (1999). Collaborative learning in an online environment. Journal of Distance Education, 14(2).

Suhaini, M., Ahmad, A., \& Harith, S.H. (2020). Factors influencing student achievement: A systematic review. International Journal of Psychosocial Rehabilitation, 24(5). https://doi.org/10.37200/IJPR/V24I5/PR201720

Sumuer, E. (2018). Factors related to college students' self-directed learning with technology. Australasian Journal of Educational Technology, 34(4). https://doi.org/10.14742/ajet.3142

Sung, Y. T., Chao, T. Y., \& Tseng, F. L. (2016). Reexamining the relationship between test anxiety and learning achievement: An individual-differences perspective. Contemporary Educational Psychology, 46, $241-252$. https://doi.org/10.1016/j.cedpsych.2016.07.001

Tan, H., Yeen-Ju, \& Neo, M. (2015). Exploring the use of authentic learning strategies in designing blended learning environments. Journal of Science and Technology Policy Management, 6(2), $127-142$. https://doi.org/10.1108/JSTPM-01-2015-0004

Thien, L. M., \& Ong, M. Y. (2015). Malaysian and Singaporean students' affective characteristics and mathematics performance: Evidence from PISA 2012. SpringerPlus, 4(1). https://doi.org/10.1186/s40064-015-1358-z

Vygotsky, L. S. (1978). Mind in society: The development of higher psychological processes. Harvard University Press.

Widiyatmoko, A. (2021). The effectiveness of google classroom as a tool to support online science learning: a literature review. Journal of Physics: Conference Series. https://doi.org/10.1088/1742-6596/1918/5/052069

Wong, S. L., \& Wong, S. L. (2019). Relationship between interest and mathematics performance in a technologyenhanced learning context in Malaysia. Research and Practice in Technology Enhanced Learning, 14(21). https://doi.org/10.1186/s41039-019-0114-3

Wunder, T. (2013). But that is unfair professor: Using a grade structure to help students understand income quintiles. Forum for Social Economics, 42(1), 70-87. https://doi.org/10.1080/07360932.2012.684100

Yamarik, S. (2007). Does cooperative learning improve student learning outcomes? The Journal of Economic Education, 38(3), 259-277. https://doi.org/10.3200/JECE.38.3.259-277

Yang, S. (2014). Wisdom and learning from important and meaningful life experiences. Journal of Adult Development, 21(3), 129-146. https://doi.org/10.1007/s10804-014-9186-x

Yang, S. (2017). The complex relations between wisdom and significant life learning. Journal of Adult Development, 24(4), 227-238. https://doi.org/10.1007/s10804-017-9261-1

Yu, R., \& Singh, K. (2016). Teacher support, instructional practices, student motivation, and mathematics achievement in high school. The Journal of Educational Research, 111(1), 81-94. https://doi.org/10.1080/00220671.2016.1204260 